\title{
Haemostatic And Haematological Indices Of Aqueous Extract Of Gongronema Latifolium On Female Albino Rat
}

\author{
Oguwike F.N, Okpala C.N, Ofor C.C \\ Department of Physiology, Anambra State University Uli, Anambra State, Nigeria. \\ Department of Medical Biochemistry, Anambra State University, Nigeria.
}

\begin{abstract}
The haematological and haemostatic effect of the aqueous extract of Gongronema latifolium was investigated. Twenty-eight (28) albino rats weighing 180-200g were divided into three groups; A (8 rats), B (10 rats) and $C$ (10 rats). The group A served as control and was given normal rat pellet and water ad libitum while the test groups $B$ and $C$ were given $1.0 \mathrm{ml}$ of the aqueous extract of Gongronema latifolium in combination with the normal rat pellet and water and a low and high dose respectively. The feeding process lasted for 28 days. On the $29^{\text {th }}$ day, $2.0 \mathrm{ml}$ of blood sample was collected by cardiac puncture for haematological analysis after a cut was made on the tail of the rats using a lancet and blade. The blood samples was used for the analysis of the haemostatic indices. The result showed that the mean haemoglobin concentration, packed cell volume, platelet count and total white blood cell count significantly decreased at $P<0.05$. Also there was a significant decrease in the mean value of bleeding and clotting time at $P<0.05$. This decrease was found to be dose dependent. Key words: Gangronema latifolium, platelet count, bleeding time, clotting, packed cell volume, albino rats.
\end{abstract}

Accepted Date: 17 June 2013

\section{Introduction}

Gongronema latifolium belongs to the Asceipiadaceae family. It is an edible rainforest plant native in the South Eastern part of Nigeria. It is a herbaceous shrub with green leaf, yellow flower and stem that yields exudates when cut. The leaves are simple, opposite or occasionally whorled, very rarely alternate, usually without stipules and the margin are nearly always entire. Gongronema latifolium is locally called "utasi" by the Ibibios, Quas and Efiks, "utazi" by the Igbos, "arokeke" by the Yorubas, Akan Asante Aborode-aborode and Sever Gasule by the Ghanaians and Senegalese respectively ${ }^{2}$. Report from health and nutritional benefit of Gongronema latifolium ${ }^{16}$. The ethanolic root extract contains polyphenol in abundance with alkaloids, glycosides, saponins and reducing sugars in moderate amount ${ }^{3}$. The plant extract has as antioxidant potential, anti-ashatic property, anti-inflammatory, antioxidant effect, anti-plasmodal activity and antisickling potential ${ }^{3,5}$, ${ }^{15}$. These supports its use in the local treatment of malign cough and stomach disordes ${ }^{6}$. The methanol and aqueous extract of Gongronema latifolium is used in the treatment of diabetes and hypertension through its antidiabetic action is more efficacious in combination with other plant as Vermonia amygdaline ${ }^{1,7,10}$. The use of Gongronema latifolium in treatment of hypertension may have significant effect in moderating incident of myocardial infarction in both diabetic and non-diabetic users ${ }^{1,7}$. The roots and stem of the plant are used as chewing stock or liquor in Sierra Leone ${ }^{8}$. The purpose of this study is to determine the effect of aqueous leaf extract of Gongronema latifolium in the haemostatic and haematological parameters of albino rat in view of finding out its effect on the haemoglobin concentration, total WBC count, Packed cell volume, platelet count, bleeding time and clotting time.

\section{Material And Methods}

Twenty-eight female albino rats were randomly selected and kept in a metal cage with iron netting in a laboratory environment. There were kept in the animal house for 21 days to get acclimated to the environment before commencing an acute feeding with the extract for 28 days.

\section{Experimental Designs}

Twenty-eight albino rats (180-200g) were selected and divided into three groups. Rats in group A served as control while those in group B and group C served as experimental animals. The group A rats were fed with normal rat pellet and water ad libitum. Group B rats were given rat pellet in addition to the oral administration of $1.0 \mathrm{ml}$ (low dose) of the leaf aqueous extract of Gongronema latifolium once daily while the group $\mathrm{C}$ were given in addition to the normal rat feed and water, $1.0 \mathrm{ml}$ (high dose) of the leaf aqueous extract of Gongronema latifolium twice daily. 


\section{Preparation Of Extract}

Fresh leaves of Gongronema latifolium were purchased from Afor Egbu market Uli. The botanical identification and authentication was confirmed at the Department of Biological Science, Anambra State University Uli. The leaves were washed, sun dried for 18 days. The dry sample was crushed to powder using a mechanical blender. The powdered leaves were stored in a glass bottle with a plastic screw cap and kept in a refrigerator $\left(4^{0} \mathrm{c}\right)$. The leaves were homogenized with distilled water by shaking and kept for 12 hours. The mixture were filtered with Whatmann No. 1 filter paper. The filtrates were concentrated to one-tenth $(1 / 10)$ of the original volume at $38-40^{\circ} \mathrm{c}$ using a rotary evaporator. The aqueous extract was freeze dried yielding a brown powder. The powders were resuspended in distilled water before use ${ }^{9}$. The extract was administered orally.

\section{TOXICITY STUDY $\left(\mathrm{LD}_{50}\right)$}

The $\mathrm{LD}_{50}$ of the extract in albino rat was determined using Lorke's method ${ }^{14}$. Albino rats (180-200g) were fasted overnight for 12 hours and doses of the extract $(10 \mathrm{mg} / \mathrm{kg})$ was administered intraperitionealy to the groups of the rats $(\mathrm{n}=3)$ and observed for $24-48$ hours. When no death occurred, subsequent doses $(15 \mathrm{mg} / \mathrm{kg}$, $29 \mathrm{mg} / \mathrm{kg}$ body weight) were administered to fresh groups of rats $(\mathrm{n}=3)$ and observed for another $24=48$ hours. The rats that served as control received normal saline only. The $\mathrm{LD}_{50}$ for the extract was calculated by geometric mean of the dose killing none of the three rats in the group and dose killing all the animals in the group.

$\mathrm{LD}_{50}=$

Dose killing all animals in the group $\mathrm{x}$ Dose killing none of the animals in the group.

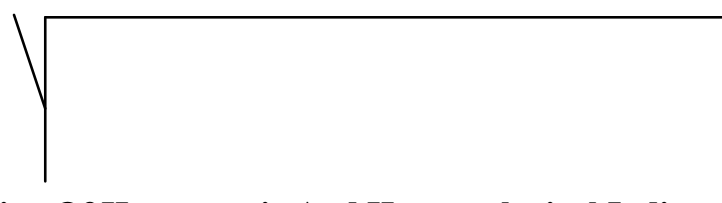

\section{Determination Of Haemostatic And Haematological Indices}

Blood samples were collected into EDTA sequstene bottles from the animal by cardiac puncture. The haematological studies were done within hours of collection of the blood sample while the haemostatic analysis were carried out immediately and directly. The packed cell volume was determined according to the haematocrit method. The haemoglobin concentration was estimated according to the Cyanmethaemoglobin method as described by Alexandar Cirffiths ${ }^{11}$. The total white blood cell count and platelet count were estimated according to the visual method of Dacie and Lewis ${ }^{12}$. The whole blood clotting time and the bleeding time were carried out by the method of Dejana ${ }^{13}$.

\section{Results}

Table 1: shows the mean and standard deviation for haemoglobin concentration, total white blood cell count, platelet count and packed cell volume of control albino rats and those fed with the aqueous extract of Gongronema latifolium.

\begin{tabular}{|l|l|l|l|l|l|}
\hline GROUP & $\begin{array}{l}\text { PLATELET } \\
\text { COUNT }(x+\text { S.D) }\end{array}$ & $\begin{array}{l}\text { Haemoglobin } \\
\text { Conc }(x+S . D)\end{array}$ & $\begin{array}{l}\text { PCV (\%) } \\
(x+S . D)\end{array}$ & $\begin{array}{l}\text { Total WBC } \\
(\mathrm{X}+\text { S.D })\end{array}$ & P Value \\
\hline $\begin{array}{l}\text { Group A } \\
\text { Control n=8 }\end{array}$ & $186.5+12.50$ & $11.10+0.7483$ & $38.38+2.6592$ & $4,325+319.60$ & \\
\hline $\begin{array}{l}\text { Group B Low } \\
\text { Dose n=10 }\end{array}$ & $107.5+14.00$ & $7.42+0.9998$ & $30.80+1.3984$ & $3,725+147.67$ & $\mathrm{P}<0.05$ \\
\hline $\begin{array}{l}\text { Group C High } \\
\text { Dose n=10 }\end{array}$ & $87.5+14.39$ & $5.20+0.7944$ & $22.40+1.3984$ & $2,870+133.75$ & $\mathrm{P}<0.05$ \\
\hline
\end{tabular}

TABLE 2: This shows the mean and standard deviation for bleeding time and clotting time of control albino rats and those fed with the aqueous extract of Gongronema latifolium at a low and high dose for a period of 28 days.

\begin{tabular}{|l|l|l|l|}
\hline GROUPS & Bleeding Time (mins) (x+S.D) & $\begin{array}{l}\text { Clotting Time (mins) } \\
(\mathrm{x}+\text { S.D) }\end{array}$ & P.Value \\
\hline Group A Control $\mathrm{n}=8$ & $4.96+0.3973$ & $3.29+0.4036$ & \\
\hline Group B Low dose $\mathrm{n}=10$ & $3.95+0.4913$ & $1.84+02648$ & $\mathrm{P}<0.05$ \\
\hline $\begin{array}{l}\text { Group C High dose } \\
\mathrm{n}=10\end{array}$ & $3.76+0.3410$ & $1.82+0.5718$ & $\mathrm{P}<0.05$ \\
\hline
\end{tabular}




\section{Discussion}

Gongronema latifolium leaf aqueous extract have an effect on the haematological system as well as haemostatic indices of test rats. In this study, the test rats fed with the extract recorded significant decrease in haemoglobin concentration, total white blood cell count, packed cell volume and platelet count $(\mathrm{P}<0.05)$ as shown in table 1 . There was also a decrease in the haemostatic indices (bleeding and clotting time) of those fed with the extract when compared with the control as in table 2 . This is of a great advantage to the health of newly delivered mothers and that is why South Easterners make this plant an important part of every diet of every woman that just delivered.

This decrease in the $\mathrm{Hb}$ concentration could be as a result of the absence of vitamin $\mathrm{B}_{12}$ an important vitamin required in haematopoiesis. That is why newly delivered mothers ought to combine it with haematinins. This vitamin from previous research was not recorded to be present. This could then lead to a clinical condition called anemia which is defined as a decrease in the number of RBCs or less than the normal quantity of haemoglobin in the blood. The decrease in the packed cell volume with dosage could be as a result of the decrease in the $\mathrm{Hb}$ concentration. The total WBC count was also decreased and could be due to the present of saponins and some other toxic photochemical that arte linked to the lysis of blood c ells and then could probably be involved on the suppression of white blood cells synthesis. The low platelet count recorded could have resulted from the resultant decrease in $\mathrm{Hb}$ concentration and packed cell volume. This suggest the likely occurrence of thrombocytopenia which is characterized by acute leukemia, aplastic and pernicious anemia and can also cause abnormalities in haemostasis ${ }^{17}$. The bleeding and clotting time was decreased when compared the control group. The decrease could be due to an increase in the production of one of the several clotting factors. It can then be deduced from this study that Gongronema latifolium leaf aqueous extract possesses an element that can affect coagulation and it lowers the haematological parameters of albino rats.

\section{References}

[1]. EDET E.E, AKPANABIATU M.I, ENO A.E, UMOH I.B, ITAN E.H (2009). Effect of Gongronema latifolium crude leaf extract on some cardiac enzymes of alloxan-induction induced rats. African Journal of Biochemistry; 3(11) 366-369.

[2]. AKINNUGA .A, BAMIDELE O, EKECHI P, ADENIYI O, (2011). Effect of ethanolic leaf extract of Gongronema latifolium on haematological same parameters in rats. African Journal of Biomedical Research; 14 (2); 153-156.

[3]. ANTAI A.B (2009): Phytochemistry and some haematological changes following oral administration of ethanolic root extract of Gongronema latifolium. Nigerian Journal of Physiological Science; 24(1): 79-83.

[4]. ATAWODI (2005): Antioxidant of potention of African Medical plants. African Journal of Biotechnology, 4(2): 128-133.

[5]. EGUNYOMI A, MOODY J.O, ELETU O.M (2009). Anti-sickling activities of two ethnomedical plant recipes used for the management of sickle cell anemia in Ibadan, Nigeria. African Journal of Biotechnology 8(11): 20-25.

[6]. SONIBARE M.A, GBILE R.O (2008): Ethnomedical survey of anti- asthmatic plants in South Eastern Nigeria. African Journal of Traditional, Complementry and Alternative medicine 5(4): 340-345.

[7]. MFON I.A, ITEM J, ATANGWHO, AMABE AKPANTAH, VICTOR A, FISKHER, ANOZENG .O. IGRI AMD PATRICK E. EBONG (2011): Effect of Combined leaf extract of Vermonia amygdalina (bitter leaf) and Gongronema latifolium (utazi) on the pancreatic B-cells of streptozotoan induced diabetic rats. British Journal of Medicine and Medical Research. 1(1) p 24-34.

[8]. ONIKE RAHAMAN (2010): A survey of medicinal values of Gongronema latifolium (madumaro) In African Alternative Medical.

[9]. UGOCHUKWU N.H, BABADY N.E, COBOURNE M, GASSET S.R, (2003): The effect of Gongronema latifolium extract on serum lipid profile and oxidative stress in hepatocytes of diabetic rats. Journal of Bioscience 28(1) 1-5.

[10]. OKAFOR J.C (1981); Woody plants of nutritional importance in traditional farming system of Nigeria humid tropics, Ph.D thesis, University of Ibadan, Ibadan.

[11]. ALEXANDER R.R and GRIFITHS J.M (1993). Haematological in: Basic Biochemical methods $2^{\text {nd }}$ Ed. John Willey and Sors, Inc. Publication. Mew York. Pp 186-187.

[12]. DACIE J.K and LEWIS S.M (1991). Practical Haematological London. Churchill Livingstone pp 566.

[13]. DEJANA E. VILLA, DEGATANO G (1982). Bleeding time in rats. A comparison of different experimental conditions. Thromb. Haemostat 48:108-111.

[14]. LORKE D (1983). A new approach to practical Acute Toxicity testing. Arch. Toxicol 54: 275-278.

[15]. MOREBISE O. FAJUNSO, MAKINDE T.M, OLAYIDE O.A, AWE E, (2002). Anti-inflammatory properties of Gongronema latifolium. African Journal of Biochemistry; 16: 575-577.

[16]. ELEYINMI F. AFOLABI (2007): Chemical composition and antibacterial activity of Gongronema latifolium. Journal of Zhejiang University Science B: 8(5): 352-358.

[17]. GUYTON A.C, HALL J, (2006): Textbook of medical Physiology $11^{\text {th }}$ Ed. Elsevier Inc. New Delhi India P4, 419-428, 457-467. 